\title{
MAKAPIOI: UM ESTUDO DE ETIMOLOGIA E SIGNIFICADO CULTURAL
}

\author{
Renata Ferreira Fernandes (PPGLC/UFRJ) ${ }^{5}$ \\ Fernanda Lemos de Lima (UERJ-PPGL/UFRJ -PPGLC)
}

\section{Resumo:}

A concepção de felicidade e sua representação na vida do homem tem sido objeto de estudos dos grandes pensadores desde a Antiguidade clássica, pois ela parece mudar de significação de acordo com as pessoas e com as épocas. Levando em consideração que o Novo Testamento foi escrito a partir de um dialeto grego e que os judeus viviam sob a influência greco-romano, pretende-se tentar vislumbrar a

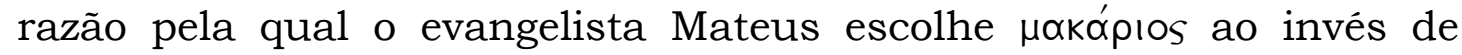

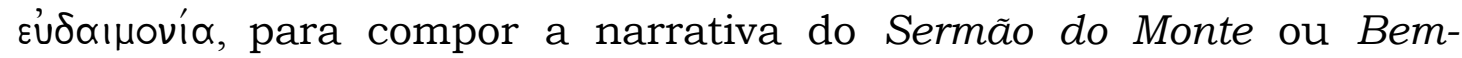
aventuranças, Mt.5.1-12, uma vez que a palavra mais utilizada pelos

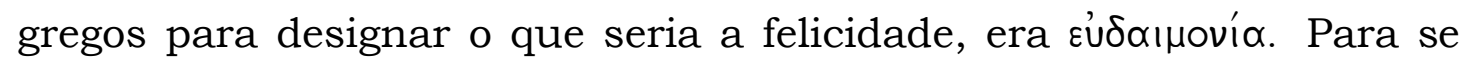
chegar ao resultado pretendido dessa investigação será apresentado um estudo etimológico e sociocultural do léxico $\mu \alpha$ kópıos e uma comparação com as significações encontradas, anteriormente, para o vocábulo

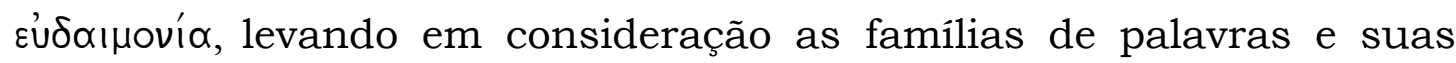
respectivas raizes.

Palavras-chaves: makários; eudaimonía; etimologia; cultura; Sermão do Monte

\section{MAKAPIOI: A STUDY OF ETIMOLOGY AND CULTURAL SIGNIFICANCE}

\begin{abstract}
:
${ }^{5}$ Bolsista da CAPES durante o mestrado. Mestra do Curso de Letras Clássicas na linha Interdisciplinar da Antiguidade Clássica - Faculdade de Letras - UFRJ - refernandes@msn.com
\end{abstract}


The conception of happiness and its representation in the man life has been object of studies of the great thinkers since classical antiquity, for it seems to change in meaning according to people and times. Taking into account that the New Testament was written from a Greek dialect and that Jews lived under Greek-Roman influence, it is intended to try to discern the reason why the evangelist Matthew

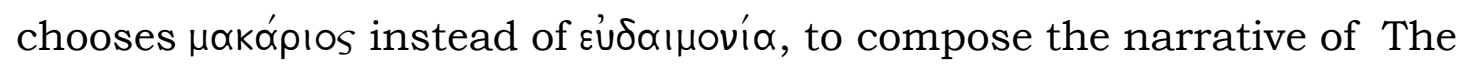
Sermon on the Mount or Beatitudes, Mt.5.1-12, since the word most used by the Greeks to designate what would be happiness, it was

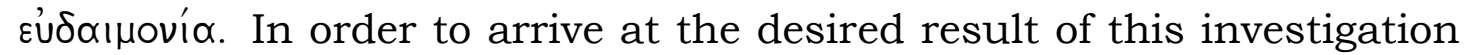
will be presented an etymological and socio-cultural study of the lexicon

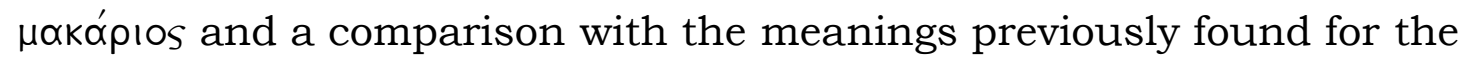

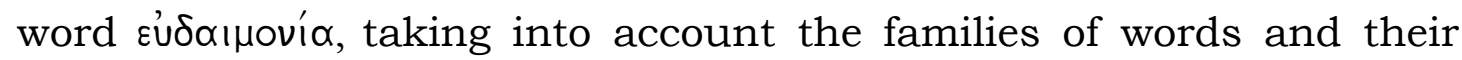
respective roots.

Keywords: makários; eudaimonia; etymology; culture; Sermon on the Mount

\section{INTRODUÇÃO}

A lingua grega é tida como uma das mais antigas do mundo e durante um bom período da história humana esteve em grande destaque como uma língua de grande prestígio associada a grandes conhecimentos. Até hoje, as áreas das ciências se utilizam, muitas vezes, de seus léxicos para expressar seus saberes e descobertas.

$\mathrm{Na}$ Antiguidade, os helenos eram referência de cultura e desenvolvimento e consequentemente seu idioma foi fortemente disseminado entre os povos existentes neste período. Segundo Horta (1978:16), "helenizar-se, de fato, era para os Gregos antigos "falar 
grego", em primeiro lugar, depois então "pensar como um grego", portanto, "viver à maneira dos Helenos".

De acordo com José Ribeiro Ferreira (2004:195), no período helenístico, a cultura grega estava consideravelmente espalhada pela Ásia e pelo Egito e exerciam forte influência por onde passavam. Nesta época, “o nome dos Gregos já não parece ser usado para designar uma raça, mas uma mentalidade, e chamam-se Helenos mais os que participam da nossa cultura do que os que ascendem a uma origem comum" (2004:196)

Para o autor, a difusão do helenismo e a fusão de culturas são marcas registradas deste período, em que tanto os gregos estavam abertos a receber os novos helenizados como os bárbaros se permitiam helenizar, o que se pode comprovar com os exemplos dos egipcios que passaram a ter uma divindade mista que pudesse ser adorada por gregos e indígenas e pela comunidade judaica, que "de modo geral, não se sentiam deslocados na vasta Cosmópolis dos reinos helenísticos e consideravam também como sua a cultura grega que neles vigorava”. (2004:195, 196) Sendo assim, eles utilizaram-se da língua grega, o dialeto $\mathrm{kolv \eta /,} \mathrm{para} \mathrm{traduzir} \mathrm{seus} \mathrm{textos} \mathrm{sagrados,} \mathrm{a} \mathrm{Septuaginta,}{ }^{6}$ e mais tarde dão continuidade a essa tradição linguística quando vão registrar os ensinamentos de seu mestre nos livros do Novo Testamento.

Não se pode negar que os judeus, na época em que o discurso das Bem-aventuranças ou Sermão do Monte, Mt. 5.1-12, foi pronunciado e posteriormente redigido, estavam totalmente familiarizados com os pensamentos e ideologias formuladas pelos gregos, no entanto, é evidente que essa absorção cultural não se dá por completo, uma vez que escolhem um vocábulo diferente do senso comum filosófico para representar uma das maiores buscas da humanidade, a felicidade.

De acordo com a Análise do Discurso, “a palavra é capaz de registrar as fases transitórias mais intimas, mais efêmeras das

\footnotetext{
${ }^{6}$ Tradução do Pentateuco Hebraico para o dialeto koıvń da língua grega. (CHAMPLIN, S/D)
} 
mudanças sociais" (BAKHTIN, 2014:41), portanto, se faz necessário tentar perceber as razões pelas quais os evangelistas do Novo Testamento escolheram uma nova palavra para representar os ensinamentos de seu mestre, pois para Orlandi (2015:36), "todo discurso é ideologicamente marcado. É na lingua que a ideologia se materializa", pois "não há discurso sem sujeito e não há sujeito sem ideologia: o indivíduo é interpelado em sujeito pela ideologia e é assim que a lingua faz sentido." (PÊCHEUX (1975) apud ORLANDI (2015:15).

Para tentar compreender quais os sentidos produzidos para se compor o que é a felicidade, nakópıos, dentro do corpus, Mt. 5.1-12, e consequentemente, do cristianismo, buscou-se primeiramente, ${ }^{7}$ tentar

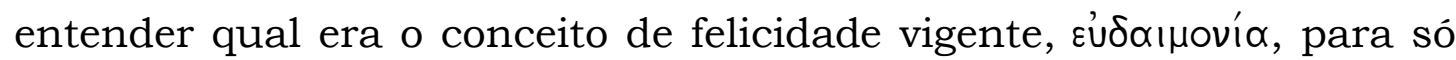
então, adentar na busca etimológica e cultural do adjetivo $\mu \alpha$ kópıos, e suas inevitáveis comparações, buscando seus pontos de contato e de distanciamentos, tentando pensar as possiveis possibilidades de recusa

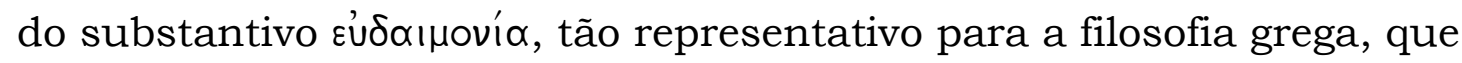
é base de todo pensamento filosófico ocidental.

\section{A EY $\triangle A I M O N I A$}

No artigo EY $\triangle A I M O N I A$ : um estudo de etimologia e significado

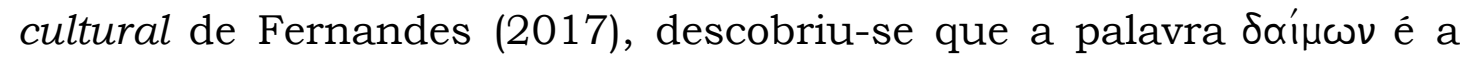

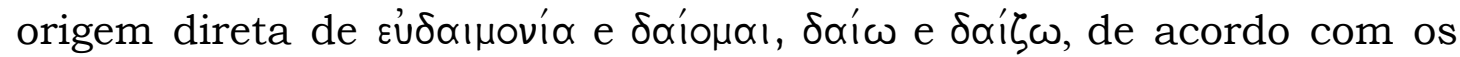
dicionários estudados ${ }^{8}$, são suas possiveis origens remotas. Porém, mesmo não podendo determinar com exatidão a origem, podemos

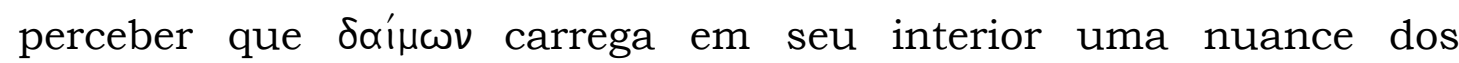
significados: dividir, compartilhar, destruir, queimar, rasgar, etc., talvez venha daí a noção pejorativa que predominou posteriormente em

\footnotetext{
7 FERNANDES, Renata F. EY $\triangle A / M O N I A$ : um estudo de etimologia e significado cultural Principia, pg 47 - 60, 2017, Rio de Janeiro, RJ, ISSN 1415-6881

8 BAILLY, 2000; CHANTRAINE, 1968, LIDDLE, SCOTT, 1996; MAGNIEN, LACROIX, 1969, MALHADAS, D.; DEZOT'TI, M. C. C.; NEVES, M. H. M, 2006, 2007, 2008, 2009, este último, não apresenta a origem etimológica de $\delta \alpha i ́ \mu \omega \nu$.
} 


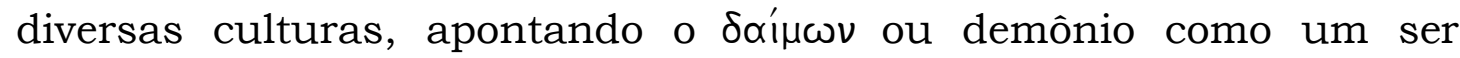
malévolo que traz destruição e diversas calamidades e desgraças para a humanidade.

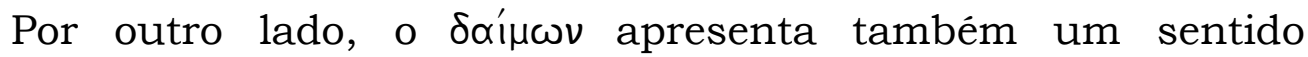
divinatório, que apesar das nuances é sempre registrado nos dicionários e nos livros como um deus, semideus, um intermediário ou até mesmo a alma de um morto, ficando claro que ele é um ser que não se enquadra na esfera humana comum, estando sempre no âmbito divino e de certa forma místico e as vezes até mesmo mítico. Fica claro também, que eles são seres atemporais, não estando presos a nenhuma época e não pertencendo a nenhuma cultura, uma vez que diversos povos de diversos locais e de períodos históricos diferentes narram seus feitos e poderes. Como nos demonstra Beaujeu apud Karol $(2016: 9,10)$, em concordância com todos os outros autores mencionados na pesquisa:

Em todos os países, em todos os tempos, acha-se comumente disseminada a crença em seres sobrenaturais, de uma categoria inferior à dos deuses, intervindo diretamente no rumo das coisas e especialmente dos negócios humanos, seres benéficos, maléficos ou indiferentes, com quem o homem busca conciliar-se mediante práticas religiosas ou mágicas; é o povo temivel e inumerável dos espíritos, demônios, anjos e gênios de toda espécie, invisiveis, ativos e perturbadores. (BEAUJEU, 2002, p. 184)

Sabe-se que originalmente os doíluoves não tinham essa diferenciação entre bons e maus. Eles eram seres neutros e na filosofia

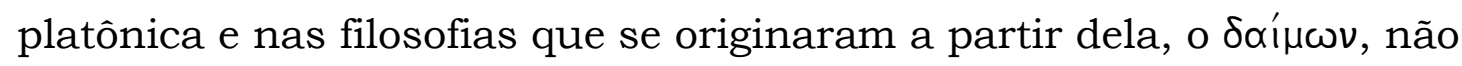
tinha conotação negativa, era, na verdade, um auxílio pedagógico, um ser que algumas vezes é entendido como interior e outras como exterior ao homem, mas que de forma geral servia para auxiliar o ser humano a não fazer escolhas erradas. 
No cristianismo e no próprio judaísmo havia desde o princípio a recusa a contatos e influências que permeassem o contexto místico, advinhatório e que contemplassem outras formas de divindades, de qualquer tipo, que não fosse somente o auxílio e amparo do Deus de Israel. A Bíblia é recheada de exemplos que demonstram essa proibição e a atuação maléfica e perturbadora causada por esses seres. ${ }^{9}$

Entre ti não se achará quem faça passar pelo fogo a seu filho ou a sua filha, nem adivinhador, nem prognosticador, nem agoureiro, nem feiticeiro; Nem encantador, nem quem consulte a um espírito adivinhador, nem mágico, nem quem consulte os mortos; Pois aquele que faz tal coisa é abominação ao Senhor; e por estas abominações o Senhor teu Deus os lança fora de diante de ti. Dt. 18.10:12 10

Essa conduta, vem sendo passada de geração em geração, da época do Velho Testamento até os dias da Nova Aliança.

Aconteceu que, indo nós para o lugar de oração, nos saiu ao encontro uma jovem possessa de espírito adivinhador, a qual, adivinhando, dava grande lucro aos seus senhores. Seguindo Paulo e a nós, clamava, dizendo: Estes homens são servos do Deus Altíssimo e vos anunciam o caminho da salvação. Isto se repetia por muitos dias. Então, Paulo, já indignado, voltando-se, disse ao espírito: Em nome de Jesus, eu te mando: retira-te dela. E ele na mesma hora, saiu. At. 16.16-18 11

No entanto, de acordo com a pesquisa feita por Fernandes (2017), os judeus não eram os únicos que eram contra os espíritos malignos, começando pelos sumérios que já tinham um grande número de terminologias e práxis a esse respeito, vários outros povos também relatam essas aparições demoníacas, de tal forma, que fica registrado que os judeus não as influenciaram e o único registro de alteração do

\footnotetext{
${ }^{9}$ No Antigo Testamento: Ex.22.18; I Sam. 28.3. No Novo Testamento: Mc.1.26; 30-32; Lc. 13.11,12 e muitos outros tanto no AT quanto no NT.

${ }^{10}$ Velho Testamento

${ }^{11}$ Novo Testamento
} 
que já era visto e praticado por outras nações é a ideia de que o nome de Jesus é o único capaz de expulsar e libertar a humanidade desse mal.

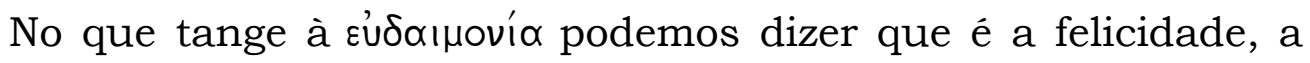
fortuna ou a prosperidade conquistada ou adquirida de acordo com a

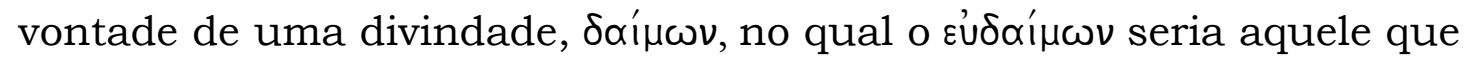
traria a boa sorte e a boa fortuna, uma vez que o advérbio eu agrega o sentido de bondade e de abundância à divindade e o kơoớ̛́ $\mu \omega \nu$ é aquele que traria a má sorte ou a má fortuna, já que o adjetivo kokós, ń, óv agrega o sentido de mau, maldade à divindade. Uns vão acreditar que

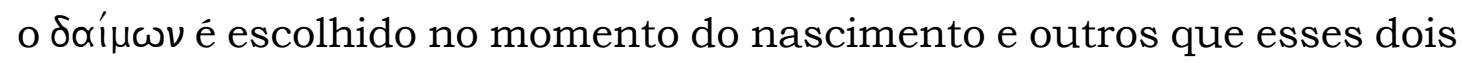
seres disputariam o tempo todo sobre o controle do individuo em questão. Independentemente da (s) vertente (s) verdadeira (s) podemos afirmar que para os gregos e para alguns povos a felicidade estaria

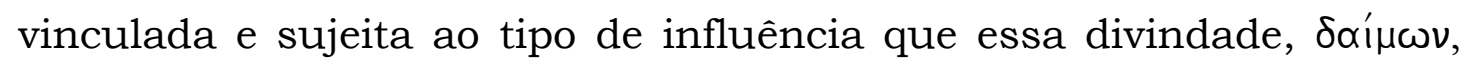
exercia sobre o homem e sobre a humanidade em geral.

Em vista disto, torna-se praticamente impossivel que tal palavra entrasse para o contexto judaico-cristão com uma conotação neutra, que dirá positiva, sendo assim os dóínoves entram para o vocabulário destes grupos como seres malignos e diretamente opostos ao Deus de Israel e seus seguidores.

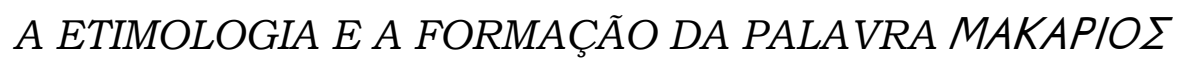

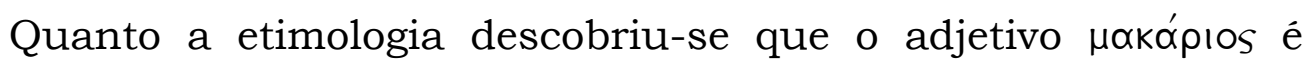
formado por derivação sufixal, no qual temos o termo-radical $\mu \alpha k \alpha \rho-$ mais o sufixo - los formador de adjetivos, que indica relação, conveniência, origem. Segundo o dicionário etimológico do Chantraine

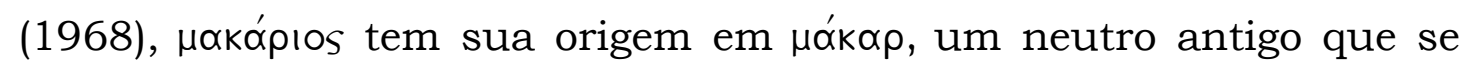
tornou adjetivo. As formas raras $\mu \alpha \alpha_{k} \alpha \rho$ e $\mu \alpha \alpha_{k} \alpha \rho s$ caracterizam a palavra como nominativo, singular, masculino e não apresentam etimologia. A hipótese de um empréstimo egípcio se mostra improvável. Quanto a 


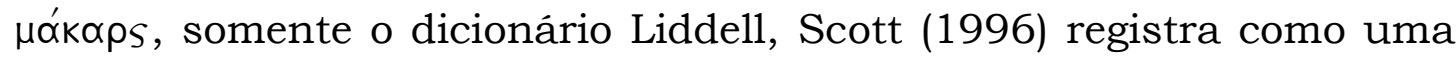
forma do dialeto eólico.

O autor também registra que a forma mais usual é $\mu \alpha \alpha_{k} \alpha ı \alpha$, significando bem-aventurado, que quando se refere aos deuses, muitas vezes aparece no plural, mas pode ser dito dos homens e até mesmo de

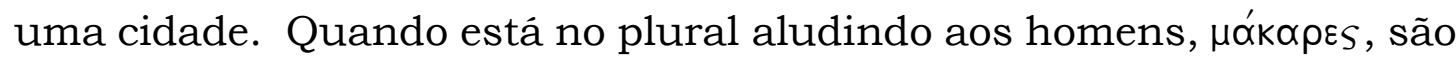
os mortos, bem-aventurados, que residem na Ilha dos Bemaventurados.

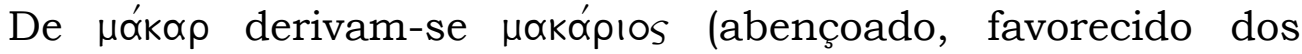

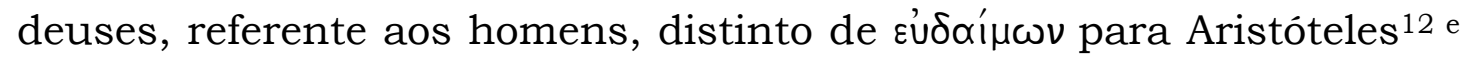

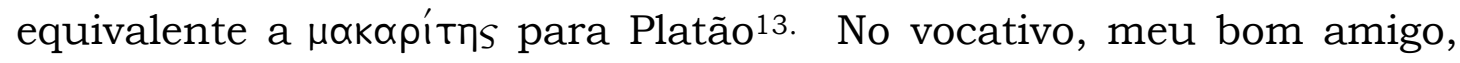

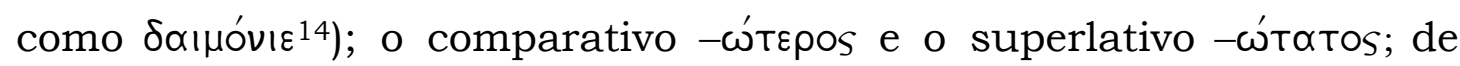

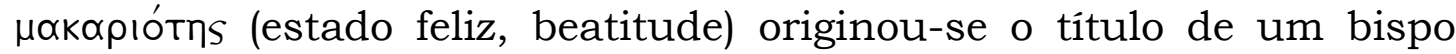

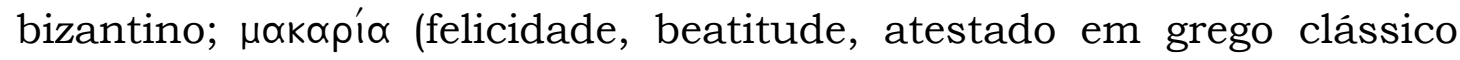

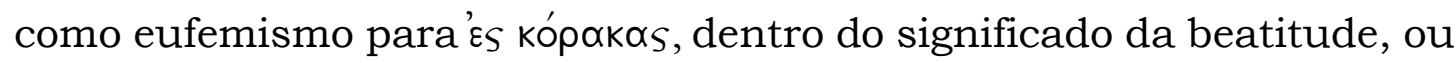

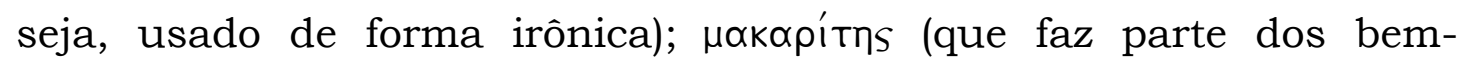

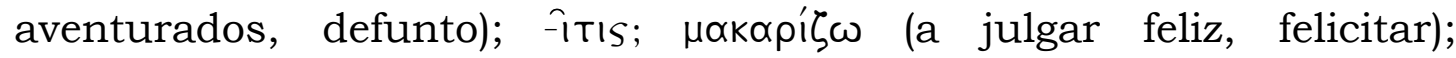

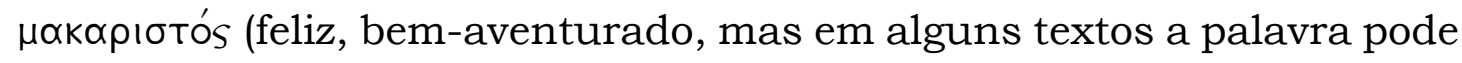
funcionar como superlativo e deve ser acentuada como proparoxitona,

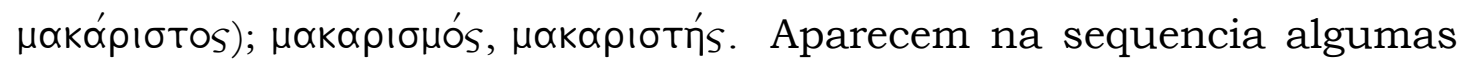

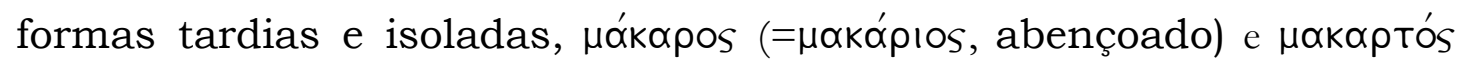

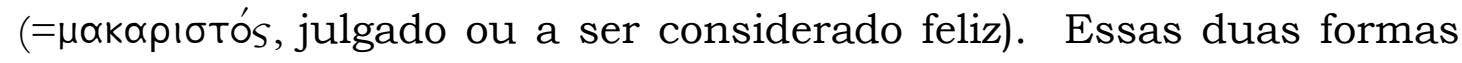
somente são encontradas no dicionário do Liddell, Scott (1996). O grego

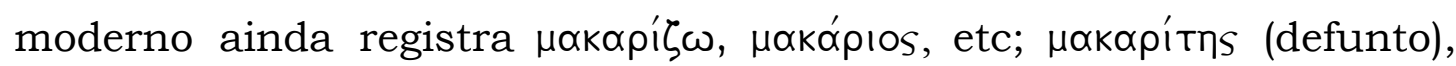

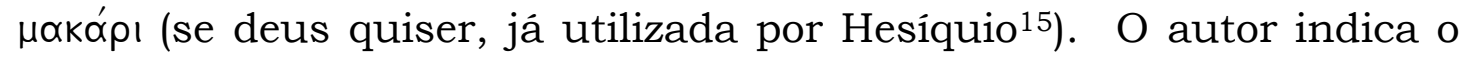
dicionário do Lampe (1961) como fonte desses léxicos dentro da literatura patrística.

\footnotetext{
${ }^{12} \mathrm{Na}$ obra,Ética Nicômaco 1101a, do filósofo

${ }^{13} \mathrm{Na}$ obra, Leis $947 \mathrm{e}$, do filósofo

14 No filósofo, Platão, etc

${ }^{15}$ De Alenxandria, lexicógrafo, V séc. d.C.
} 
Segundo os principais dicionários ${ }^{16}$ da língua grega $\mu \alpha$ á́pıos significa (homens) abençoado, divinamente feliz, bem-favorecido, na sorte, na vida, condição social, natureza, bem-aventurado, favorecido

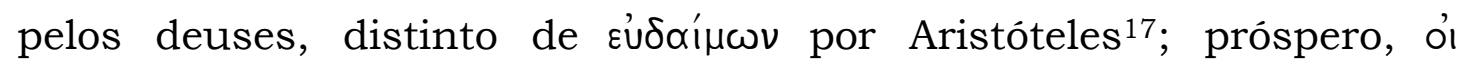

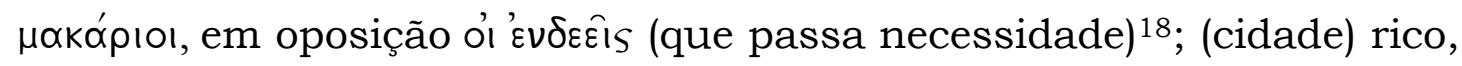
opulento, próspero; (mortos) bem-aventurados ( $\mu$ ók $\alpha \rho)$.

E Mók $\alpha{ }^{19}$ (homens) bem-aventurado, ditoso; afortunado; rico, próspero, com relação a um rei, um homem de posses, sua casa, às vezes, podendo se referir a uma cidade e no plural (deuses) os bemaventurados, epíteto dos deuses, nas tragédias de Ésquilo, os deuses infernais; (mortos) a Ilha ou Ilhas dos Bem-aventurados, às vezes confundida com os Campos Elísios, ou os heróis que, após a morte, residem na Ilha dos Bem-aventurados.

O dicionário patrístico do Lampe (1961) acrescenta palavras e termos que não foram utilizados por Liddell, Scott (1996), mas que tinham grande relevância para o contexto cristão em geral. Segundo

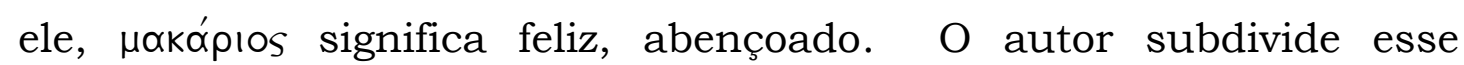
significado em sete subitens: A. epíteto divino. 1) de Deus, 2) do que pertence a Deus - a imagem de Deus nos homens; B. as outras coisas de Deus. 1) dos bons anjos, 2) do homem em Cristo, 3) o título dos santos, 4) a- os títulos eclesiásticos - os bispos de Roma, b- modo de endereços; C. Estados e atividades com Deus como objeto. 1) dos anjos, 2) do homem; D. De tudo que traz salvação ao homem: morte de Cristo; E. Em conexão com a vida por vir. 1) dos que partiram, 2) a- do estado dos fiéis que partiram, b- com referência à ressurreição geral, c- como télos (término, finalização); 3) substantivo neutro, beatitude; 4) da Jerusalém celestial; F. de objetos materiais em alegorias; G. Gnóstico.

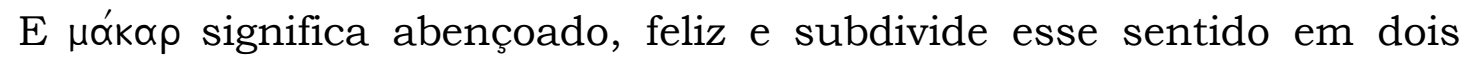
subitens: 1. de Deus, do noivo celestial, em invocação; 2. dos homens,

\footnotetext{
16 BAILLY, 2000; CHANTRAINE, 1968, LIDDLE, SCOTT, 1996; MAGNIEN, LACROIX, 1969, MALHADAS, D.; DEZOTTI, M. C. C.; NEVES, M. H. M, 2006, 2007, 2008, 2009.

${ }^{17}$ Ética Nicômaco

18 Ética Nicômaco

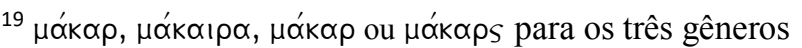


como a partilha de Deus bem-aventurança especial após a morte, de um mártir chamado Macar, no plural, os mortos bem-aventurados. Ele acrescenta duas palavras que não aparecem no Liddell, Scott (1996),

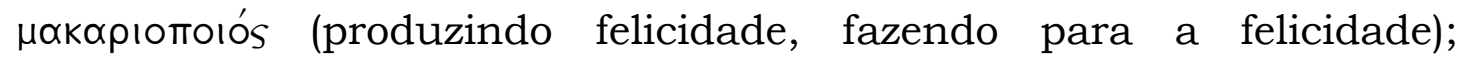

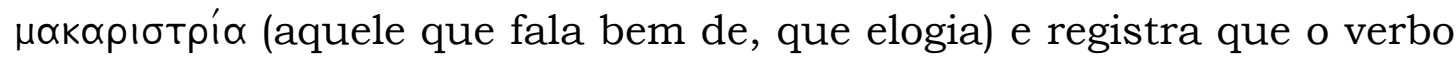

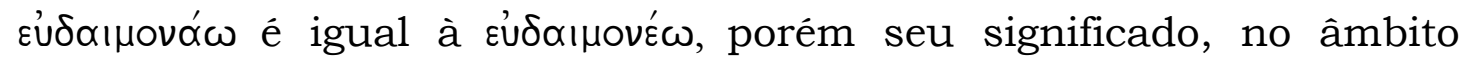
cristão, se distingui do apresentado por Liddell, Scott (1996), sendo definido por Lampe (1961) como, ser verdadeiramente feliz.

\section{SIGNIFICADO CULTURAL DE MAKAPIOS}

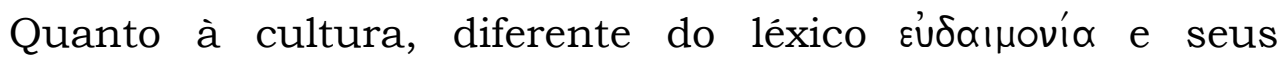
derivados que aparecem abundantemente em diversos tipos de

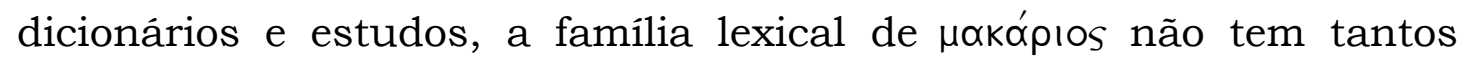
registros. No âmbito grego, tanto Grimal (2005) como Brandão (1991) narram os mesmos fatos, as possiveis vertentes das histórias de Mácar, que por vezes é confundido com Macareu, e de Macária.

Mácar aparece, na Ilíada, como um rei da ilha de Lesbos, no qual as tradições divergem sobre a sua figura: umas vezes é considerado como um dos filhos de Hélio e de Rodo, que fugiu de Rodes depois do assassinato de seu irmão Ténages e se refugiou em Lesbos , outras vezes, considera-se filho de Crinaco, filho de Zeus, e diz-se que era originário de Óleno, na Acaia. Depois do Dilúvio de Deucalião, foi para a ilha de Lesbos, comandando um grupo de iónios e de outros colonos de diversas regiões. A colônia de Mácar prosperou e, pouco a pouco, submeteu ao seu poder as ilhas vizinhas, que eram desertas nessa época. Na mesma altura, chegou a Lesbos o filho de Lapites, Lesbos, que para obedecer a um oráculo da Pítia, foi, com alguns companheiros, fixar-se na ilha de que Mácar era o rei. Casou-se com a filha deste, Metimna, e os dois povos, habitaram em conjunto a ilha, a que Lesbos deu depois o seu nome. Além de Metimna, Mácar teve outra filha chamada Mitilene. Ambas deram nomes a cidades de Lesbos. 
Outra tradição fazia de Mácar um filho de Éolo, Macareu, que se uniu, num amor incestuoso, a sua irmã Cânace. Quando soube de sua paixão, suicidou-se.

Macária, a Bem-aventurada, é a única filha que nasceu de Héracles. Sua mãe é Dejanira. Foi ela quem extinguiu a pira de seu pai na Eta. Mais tarde, foi refugiar-se com os irmãos em Tráquis, e depois em Atenas; como o oráculo decretara que a vitória sobre Euristeu só seria possível pagando o preço de uma vítima humana, Macária ofereceu-se voluntariamente para o sacrificio, assegurando assim a vitória. Em sua memória, havia, perto de Maratona, na Ática, uma fonte chamada Macária.

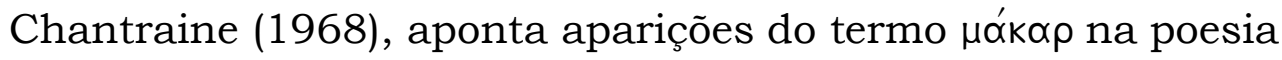

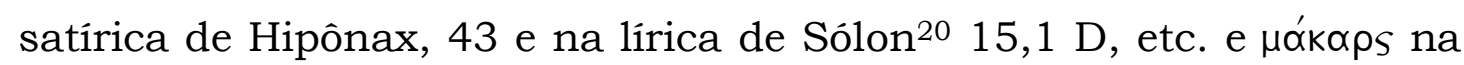
poesia lírica de Alcman $15 \mathrm{P}$ e às vezes $\mu \alpha$ ók $\alpha$ ı $\alpha$ (cf. $\left.\mu \alpha^{\prime} \alpha \propto \rho\right)$ na epopeia de Homero, na lírica de Alcman, Safo e Píndaro, na tragédia de Eurípides, etc, no entanto, não especifica a obra e local em que o léxico aparece.

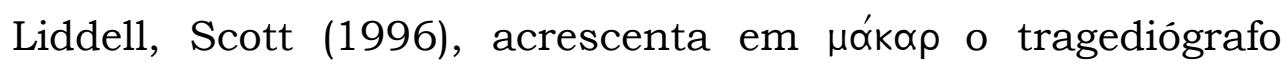
Euripides, Helena, 375, os poetas satíricos: Aristófanes Aves, 1722 e

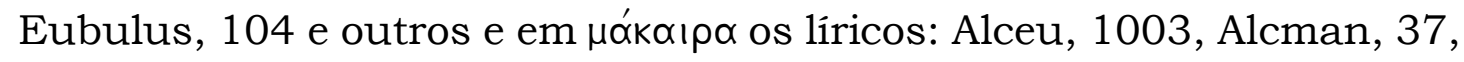
Safo, 1.13, Píndaro, Píticas, 511, etc. O dicinário do Bailly (2000) menciona o uso dessa família de palavras em Ésquilo e Magnien, Lacroix (1969) em Teócrito ${ }^{21}$.

De acordo com West (1998), encontra-se o léxico $\mu$ ók $\alpha \rho$ nos versos de Hipônax, 43, 117.6, Sólon, 4.2, 13.3, 14.1 e do elegíaco Theógnis, 204, 741, 759, 834, 1013

Rocha Pereira (1993:166, 222) diz que em Hesíodo aparece a Tha dos Bem-aventurados como o local de destino dos heróis, o que é corroborado pela II $^{\mathrm{a}}$ Olimpica de Píndaro que diz que o destino de Aquiles foi a citada ilha. Nesta Olimpica, o mito da Iha dos Bemaventurados é retomado com a crença de que "aqueles que conservam suas almas afastadas da injustiça durante três existências sucessivas

\footnotetext{
${ }^{20}$ Um dos sete sábios da Grécia

${ }^{21}$ Poeta bucólico da época alexandrina, III século a.C.
} 
têm finalmente acesso a um lugar de delícias" (1993:378). Segundo a

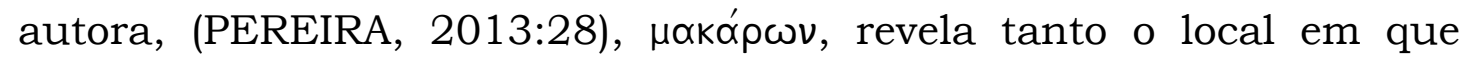
habitam como também eleva o seu estado, tornando-os semelhantes aos deuses, uma vez que esse é o epíteto que se aplicava a eles na epopeia. São registrados numerosos exemplos, em Homero, Hesíodo e nas poesias elegíacas e líricas primitivas, em que as ilhas aparecem como uma terra longinqua, provida de grande abundância de alimentos, pois a fertilidade do solo estava relacionada com a quantidade de felicidade do povo, próxima ao oceano, com facilidade de vida e o privilégio de escaparem a morte.

Peçanha e Onelley (2014: 47, 48) acrescentam que nesta mesma Olimpica, se anuncia pela primeira vez prêmios e castigos após a morte, "A Olimpica 2 o primeiro texto da literatura ocidental a apresentar a crença de prêmios e de castigos após a morte." E mencionam que antes de Píndaro o Hades era visto como a última estância dos mortos, e que independentemente das ações humanas serem boas ou ruins, não haviam castigos e nem premiações. E revelam que nem todos os estudiosos acreditam na teoria de que as ilhas estejam localizadas sobre a terra, uma vez que "levar uma vida sem sofrimentos e sem alterações não condiz com o ciclo da vida humana, sujeito à instabilidade da sorte.” (PEÇANHA, ONELLEY, 2014:51,52).

No contexto judaico-cristão, segundo Champlin (S/D:162), a Septuaginta, é sem dúvida, a mais importante versão da Bíblia hebraica. Foi provavelmente preparada em Alexandria por vários tradutores que trabalharam entre os séculos III e I a.C. Seu significado vem de "setenta" em grego, podendo ser abreviado pelo numeral romano LXX e deriva da lenda do segundo século a.C. de que 72 anciãos de Israel traduziram o Pentateuco Hebraico para o grego em meros 72 dias. Há mais de dois mil manuscritos da LXX, a maioria redigida do séc. II até o séc. XVI d.C. Todos foram cuidadosamente catalogados por estudiosos bíblicos. 
A Septuaginta foi a forma primária da Bíblia para as comunidades de judeus helenizados e, assim, foi usada pela maioria dos primeiros cristãos. Quando a Bíblia é citada no Novo Testamento, é quase sempre a partir da versão Septuaginta, que elevava seu status para os teólogos cristãos (Michael D. Coogan in Champlin:163).

O autor, (CHAMPLIN, S/D:703), ainda afirma que o termo

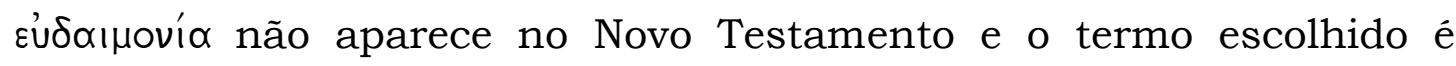

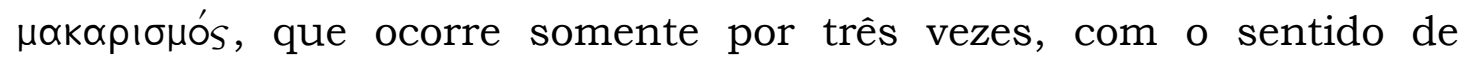
felicidade espiritual, bem-aventurança: Rm. 4.6-9,

É o caso também de Davi ao falar da bemaventurança ( $\mu \alpha \kappa \alpha \rho$ ojòv) do homem a quem Deus atribui justiça independentemente das obras: Bemaventurados ( $\mu \alpha$ kópios) aqueles cujos delitos foram perdoados e cujos pecados foram cobertos. Bem-

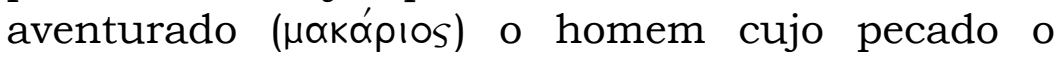
Senhor jamais levará em conta. Esta bemaventurança ( $\mu \alpha \kappa \alpha \rho$ orós) vale apenas para o circunciso, ou também para o incircunciso? Pois dizemos: No caso de Abraão a fé lhe foi levada em conta para justiça. (CHAMPLIN, S/D:703)

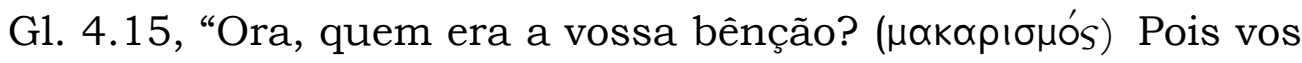
asseguro que, se fosse possivel, terieis arrancado os próprios olhos para dá-los a mim.”. A forma adjetiva e o verbo ocorrem por mais 52 vezes, destacando-se o uso da palavra no começo do Sermão da Montanha, de

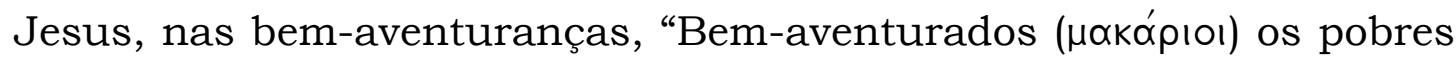
no espírito, porque deles é o reino dos céus." Mt. 5.3. No entanto, não se pode dizer que o uso da família lexical de $\mu \alpha$ kópıos seja uma inovação do Novo Testamento, pois desde a tradução da Septuaginta já se

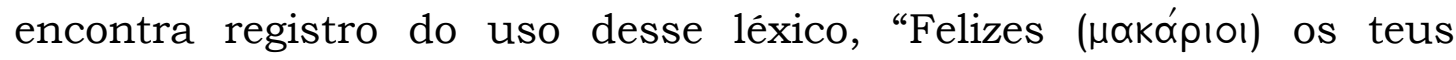

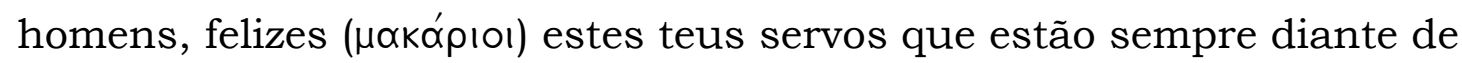
ti e ouvem a tua sabedoria!" 2 Cr. 9.7. 
CONCLUSÃO

O homem sempre buscou a felicidade, mas até os dias de hoje, nem os estudiosos clássicos e muito menos os modernos, conseguiram chegar a um consenso sobre o que seria a verdadeira felicidade, cada grupo ou indivíduo a percebe de uma maneira diferente, por isso, para se tentar entender o que um grupo pensa sobre uma determinada coisa ou concepção é necessário analisar seus discursos, sua língua e sua forma de agir e interagir com os outros e com o determinado objeto analisado, pois o discurso é um objeto sócio-histórico que sofre intervenção do linguístico (ORLANDI, 2015,14) e a "a materialidade específica da ideologia é o discurso e a materialidade específica do discurso é a lingua" (ORLANDI, 2015,15), assim, não se pode trabalhar essas questões de forma dissociada, elas atuam e interagem em conjunto, devendo ser analisada e observada da mesma maneira.

No estudo do corpus em questão, buscou-se analisar tanto as questões linguísticas como as sócio-históricas e ideológicas que são pertinentes à análise, chegando-se ao entendimento que o estudo etimológico apresentado nos aponta para uma direção de resposta, pois se sabe que o povo judaico-cristão é monoteísta e que o sentido e uso

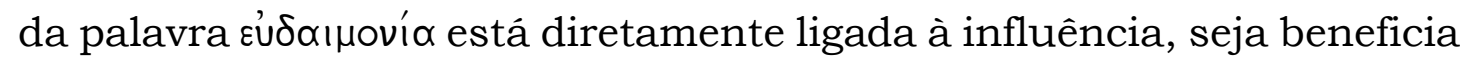
ou maléfica, do $\delta \alpha i ́ \mu \omega \nu$, que é uma divindade e por isso reprovado de acordo com as crenças e ensinamentos deste grupo.

Pode-se levar em conta também que a significação usada pelo

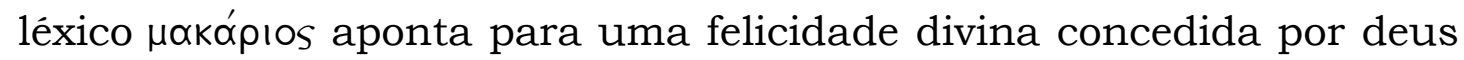
aos mortos, aos moradores da(s) Iha(s) dos Bem-avendturados, assim, seria uma felicidade que não é para este momento, para este mundo, o que se aproxima, de certa forma, com que é anunciado por Jesus e seus discipulos, uma vez que os mesmos também proclamam que o reino de Deus não pertence a esse mundo: "Respondeu Jesus: O meu reino não é deste mundo. Se o meu reino fosse deste mundo, os meus ministros se empenhariam por mim, para que não fosse eu entregue aos judeus; 
mas agora o meu reino não é daqui." Jo. 18.36 e é destinado para os seus fiéis:

Ora, as obras da carne são conhecidas e são: prostituição, impureza, lascivia, idolatria, feitiçarias, inimizades, porfias, ciúmes, iras, discórdias, dissenções, facções, invejas, bebedices, glutonarias e coisas semelhantes a estas, a respeito das quais eu vos declaro, como já, outrora, vos preveni, que não herdarão o reino de Deus os que tais coisas praticam. G1. 5.19-21

Para Bakhtin (2014:45), o signo além de ser "um consenso entre indivíduos socialmente organizados no decorrer de um processo de interação.", reflete as menores transformações sociais realizadas por um determinado grupo e para que a alteração simbólica aconteça é preciso que o mesmo sofra uma avaliação ideológica que justificará sua recusa ou inclusão em determinado domínio ideológico, pois o "signo não existe apenas como parte de uma realidade; ele também reflete e refrata uma outra." (2014:32).

Desta forma, pode-se dizer que a escolha foi feita baseada em uma ideia de felicidade que não estivesse relacionada a um contexto politeísta e nem vinculada a este mundo. O que direciona a escolha

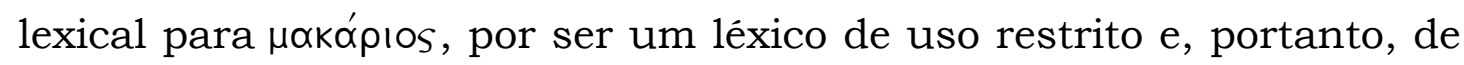
pouca utilização e disseminação entre os povos, podendo ganhar um novo sentido dentro da cultura cristã como uma felicidade, uma bemaventurança concedida por Deus aos seus fiéis em seu reino.

Embora no português ambas as palavras sejam traduzidas ora por felicidade ora por bem-aventurança, na língua grega, fica claro, que essas duas palavras têm significação e uso distintos e as vezes restritos, não podendo ser utilizados como uma sinonímia perfeita, pois, conforme Bechara (2009:404), a identidade dos sinônimos é muito relativa e no uso assumem sentidos "ocasionais", "que no contexto um não pode ser empregado pelo o outro sem que se quebre um pouco o matiz da expressão." Dessa maneira, fica evidente que apesar de se apresentarem como sinônimos nas traduções bíblicas e nas literaturas 
afins, os pequenos matizes que as diferenciam são o suficiente para que haja uma preferência por apenas um desses léxicos para representar a felicidade, a bem-aventurança da comunidade cristã.

A partir desses estudos e das comparações de significado e da

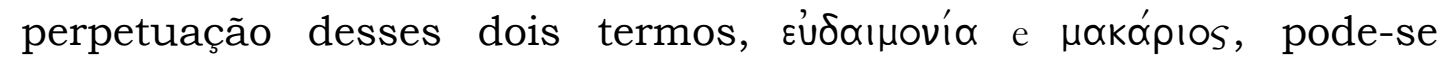
começar a delinear os motivos pelos quais o segundo termo foi escolhido, mas, por outro lado, não se pode dar por concluída essa investigação, sendo necessário para um melhor detalhamento, a verificação de outros léxicos e seus devidos contextos, já que na língua grega existem outras palavras que também podem ser traduzidas como felicidade e bem-aventurança, como é o caso dos substantivos ő入ßos - opulência, prosperidade, abundância, riqueza, felicidade mundana, felicidade material; Eưvuxía, $\alpha_{S}(\hat{\eta})$ sucesso, felicidade, boa

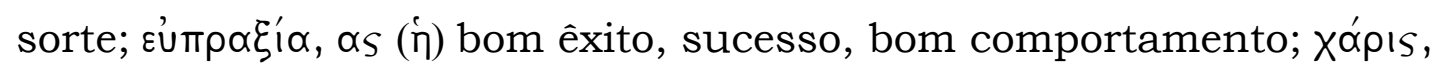
ıтoS (†) feliz, felicidade, alegre, favor, adeus e graça, etc.. E sem deixar de levar em consideração também como e quanto esses significados perduram e influenciam atualmente. 


\section{REFERÊNCIAS BIBLIOGRÁFICAS}

ALMEIDA, João Ferreira de. Trad. Bíblia de Estudo Almeida (revista e atualizada) $2^{\text {a }}$ ed. Barueri: SP: Sociedade Bíblica do Brasil, 1999.

BAILLY, Anatole. Abrégé du dictionnaire Grec Français. Paris: Librairie Hachette, 2000.

BAKHTIN, M.M. Marxismo e filosofia da linguagem: problemas fundamentais do método sociológico da linguagem. Trad. Michel Lahud \& Yara Frateschi Vieira. São Paulo: Hucitec, 2014.

BRANDÃO, Junito. Dicionário Mítico-Etimológico, $3^{\mathrm{a}}$ ed. Vol.II (J-Z) Petrópolis, RJ: Vozes, 1991.

CHANTRAINE, Pierre. Dictionnaire Étymologique de la Langue Grecque: Histoire des mots. Paris: Éditions Klincksieck, 1968.

CHAMPLIN, R.N. Enciclopédia de Bíblia, Teologia e Filosofia. Vol.2, 6. São Paulo: Agnus, S/D.

FERNANDES, Renata F. EUDAIMONIA: um estudo de etimologia e significado cultural Principia, pg 47 - 60, 2017, Rio de Janeiro, RJ, ISSN 1415-6881

FERREIRA, José Ribeiro. A Grécia Antiga - Sociedade e Política. Lisboa: Edições 70, 2004.

GOMES, Paulo Sérgio \& OLIVETTI, Odayr. Trad. Novo Testamento Interlinear Analítico. (Texto majoritário com aparato crítico). São Paulo: Cultura Cristã, 2008.

GRIMAL, Peirre, Dicionário da mitologia Grega e Romana Tradução Victor Jabouile. 5ª edição. Rio de Janeiro: Bertrand Brasil, 2005.

HORTA, Guida Nedda Barata Parreiras. Os Gregos e Seu Idioma. Tomo I, Rio de Janeiro: di Giorgio, 1978.

KAROL, Luiz. DE DEO SOCRATIS, A DEMONOLOGIA NO CONTEXTO DO IMPÉRIO GRECO-ROMANO Tese (Doutorado) - Universidade Federal do Rio de Janeiro, Faculdade de Letras, Programa de Pós Graduação em Letras Clássicas, 2016.

LAMPE, G. W. H. A Patristic Greek Lexicon. Oxford, 1961.

LIDDLE, SCOTT. A Greek-English Lexicon. New York: Oxford, 1996. 
MAGNIEN, Victor, LACROIX, Maurice, Dictionnaire Grec-Français, Paris: Librairie Classique Eugène Belin, 1969.

MALHADAS, D.; DEZOTTI, M. C. C.; NEVES, M. H. M. (coord.s)

Dicionário grego-português. São Paulo: Ateliê Editorial. Quarto Fascículo - п-p, 2009.

Dicionário grego-português. São Paulo: Ateliê Editora. Terceiro fascículo - Kappa-ômicron, 2008.

Dicionário grego-português. São Paulo: Ateliê Editorial. Segundo fascículo - Épsilon-iota, 2007.

Dicionário grego-português. São Paulo: Ateliê Editorial. Primeiro fascículo - Alfa-delta, 2006.

ORLANDI, Eni P. Análise de Discurso: Princípios \& Procedimentos. $12^{\mathrm{a}}$ ed. Campinas, SP: Pontes Editores, 2015.

PEÇANHA, Shirley; ONELLEY, Gloria - Imagens escatológicas em Olimpica 2. Humanitas. Vol. 66 (2014) .

PEREIRA, Maria Helena da Rocha. Estudos de História da Cultura Clássica. $7^{\text {a }}$ ed. Vol.I Cultura Grega. Lisboa: Fundação Calouste Gulbenkian, 1993.

Estudos sobre a Grécia antiga, dissertações Lisboa: Fundação Calouste Gulbenkian, 2013.

WEST, M.L. IAMBI ET ELEGI GRAECI - ANTE ALEXANDRUM CANTATI. Vol. I. New York: Oxford, 1998. 